\title{
Performance of Traditional Rice (Oryza sativa L.) Varieties under System of Rice Intensification during Kharif Season in South Odisha Conditions
}

\author{
Nokala Manikanta*1, Tanuj Kumar Mandal ${ }^{1}$, Sagar Maitra ${ }^{1}$ and Rahul Adhikary ${ }^{2}$
}

${ }^{1}$ Department of Agronomy, M.S. Swaminathan School of Agriculture, Centurion University of Technology and Management, Paralakhemundi-761 211, India

${ }^{2}$ Department of Soil Science and Agricultural Chemistry, M.S. Swaminathan School of Agriculture, Centurion University of Technology and Management, Paralakhemundi-761 211, India

*Corresponding author: manikanta5729@gmail.com (ORCID ID: 0000-0002-5644-7173)

Paper No. 794

Received: 10-04-2019

Revised: 20-07-2019

Accepted: 25-08-2019

\begin{abstract}
A field experiment was carried out at the Bagusala Farm, of M.S. Swaminathan School of Agriculture, Centurion University of Technology and Management, Paralakhemundi, Odisha during the kharif season of 2018. Four traditional rice varieties namely, $\mathrm{V}_{1}$, Red rice (kondo dano), $\mathrm{V}_{2}$, Manipuri black rice, $\mathrm{V}_{3^{\prime}}$, Balami and $\mathrm{V}_{4}$, Dudheshwar were taken into consideration and the treatments were laid out in Randomized Complete Block Design (RCBD) with four replications. The traditional rice variety Dudheshwar got highest values of growth attributing characteristics, yield attributes and yield of rice. The highest grain yield $\left(6560.25 \mathrm{~kg} \mathrm{ha}^{-1}\right)$ and straw yield $\left(10632 \mathrm{~kg} \mathrm{ha}^{-1}\right)$ were achieved by treatment $\mathrm{V}_{4}$-Dudheshwar. In terms of net return and benefit: cost ratio, the variety Manipuri black rice is resulted in higher profitability as compared to other traditional rice varieties.

\footnotetext{
Highlights

(0 Dudheshwar recorded highest growth, yield attributes and yield of different rice varieties under SRI.

( Manipuri black rice exhibited highest net return ( $₹ 1,17,723 \mathrm{ha}^{-1}$ ) as compared to all other traditional rice varieties.
}

Keywords: Traditional rice varieties, system of rice intensification, growth attributes, yield attributes and yield

Rice (Oryza sativa L.) is second most important food crops of the world after wheat. Rice is the staple food crop for people of south, south-east and eastern Asia where about 90 per cent of the world's rice is produced and consumed. It is grown in 114 countries across the world on an area about 160 million hectares with annual production of 494.3 million tonnes, and total supply of 711.5 million tonnes. Globally, total rice consumption was recorded 491.5 million metric tonnes in 2014-15 (Anonymous 2016). Rice is the important crop in the country's food security accounting about $44 \%$ of the total food grain production and provides $43 \%$ calorie requirement for more than $70 \%$ of Indians. In India, rice covers the highest area by a single crop and it is also maximum area among all rice growing countries. It is an important crop in India which occupied 43.9 million hectares with the annual production of 103.6 million tonnes (Anonymous, 2015). India is the second largest producer of rice after China. Being the secondary Centre of origin of cultivated rice, Orissa has the distinction of possessing about 10,000 to 15,000 traditional rice varieties out of 45,000 to 50,000 found in the world. Among these traditional rice varieties, landraces of aromatic rice bear special significance because 
of their special flavor and economic value in the present globalized era (Chaudhury 2003). Survey made in the recent past, has estimated that more than one hundred landraces of aromatic rice are found in the state (Khatana 2004; Das and Rout 2006). They are mostly short grained with pleasant aroma. Plants as well as seeds of these varieties show wide diversity with regard to various morphological and biometrical characteristics. Traditional rice varieties in India and across Asia are under serious threat of extinction due to adoption of high yielding varieties (HYVs) and hybrids. Further, the methodology of System of Rice Intensification (SRI) can be adopted for water saving as well as enhancement of productivity.

Hence, an attempt was made to assess the performance of traditional rice varieties under SRI methodology.

\section{MATERIAL AND METHODS}

The field experiment was carried out at the Bagusala Farm, of M.S. Swaminathan School of Agriculture, Centurion University of Technology and Management, Paralakhemundi, Odisha. The farm is situated at the $18.77^{\circ} \mathrm{N}$ latitude and $84.09^{\circ} \mathrm{E}$ longitudes, at an elevation of $61 \mathrm{~m}$ above mean sea level (MSL). The experimental field was a medium land with good irrigation and drainage facilities. The soil was a typical new alluvial, inceptisol and sandy loam in texture having moderate water holding capacity. The field experiment was carried out to study the performance of four traditional rice (Oryza sativa L.) varieties, namely, $\mathrm{V}_{1}$, Red rice (kondo dano), $\mathrm{V}_{2}$, Manipuri black rice, $\mathrm{V}_{3}$, Balami and $\mathrm{V}_{4}$, Dudheshwar under SRI. The treatments were laid out in Randomized Complete Block Design (RCBD) with four replications.

On $18^{\text {th }}$ August 2018, 12 days old seedlings were tranplanted with single seedling per hill and a spacing of $25 \times 25 \mathrm{~cm}$ was maintained. The half dose of $\mathrm{N}+$ full $\mathrm{P}_{2} \mathrm{O}_{5}$ and $\mathrm{K}_{2} \mathrm{O}$ were applied as basal along with FYM. Remaining $\mathrm{N}$ was divided into two equal splits and applied at 30 DAT and 45 DAT. The crop was infested with some weeds during the early stage of establishment. Two mechanical weedings were done at 30 DAT followed by second weeding at 45 DAT by cono weeder. Among the varieties, $V_{1}$, Red rice (kondo dano), $\mathrm{V}_{4}$, Manipuri black rice were harvested on $25^{\text {th }}$ November 2018 , whereas variety
$\mathrm{V}_{3^{\prime}}$ Balami was harvested on $26^{\text {th }}$ Nov 2018 and $V_{4^{\prime}}$ Dudheshwar on 11 $1^{\text {th }}$ Dec 2018.

\section{RESULTS AND DISCUSSION}

Observations on growth characters, yield attributes and yield recorded during the period of investigation were analyzed statistically and these are presented below (Table 1-5).

\section{Growth Attributes}

The observation on plant height of rice varieties was recorded at 30 days after transplanting (DAT), 45 DAT, 60 DAT, 75 DAT, 90 DAT and harvest stage and a gradual progression of plant height was noted in all rice varieties upto harvest (Table 1 ). There was a significant difference between different traditional rice varieties on expression of the plant height. The maximum plant height at harvest stage was recorded by the variety Dudheshwar $(148.43 \mathrm{~cm})$ which produced significantly taller plants than other rice varieties except Manipuri Black rice $(140.50 \mathrm{~cm})$. The lowest plant height $(102.37 \mathrm{~cm})$ was obtained by the variety Balami. Dry matter accumulation of different rice varieties was increased with the age of the crop and reached its maximum at harvest. The maximum dry matter accumulation (1419.28 $\mathrm{g} \mathrm{m}^{-2}$ ) was obtained at harvest stage by the variety Dudheshwar which differed significantly over all other traditional rice varieties (Table 2).

However, the treatment $\mathrm{V}_{2}$ (Manipuri black rice) was statistically at par with $\mathrm{V}_{3}$ (Balami). The lowest dry matter accumulation $\left(966.40 \mathrm{~g} \mathrm{~m}^{-2}\right)$ was obtained by $\mathrm{V}_{1}$ (Red rice or kondo dano). Leaf area index (LAI) of rice varieties was initially low at 30 DAT in view of slow growth rate, it was gradually increased with age of the plant and reached its maximum value at $75 \mathrm{DAT}$ and there after it declines toward the harvest probably due to leaf senescence irrespective of different varieties (Table 3). Yield of plant is closely related with LAI and increase in value of LAI enhanced the interception of light which ultimately maximized the assimilate production. At harvesting, the treatments did not show any significant effect on expression of LAI of rice. CGR was slowly increased at early stage due to low LAI and dry matter production, however, increased rapidly during 60 and 75 DAT (Table 4). There was again a decreased CGR value between 90 DAT to harvest due to senescence of leaves respective of treatments. 
Performance of Traditional Rice (Oryza sativa L.) Varieties under System of Rice Intensification...

Table 1: Plant height $(\mathrm{cm})$ of traditional rice varieties under System of Rice Intensification (SRI)

\begin{tabular}{|c|c|c|c|c|c|c|}
\hline \multirow{2}{*}{ Varieties } & \multicolumn{6}{|c|}{ Plant height $(\mathrm{cm})$} \\
\hline & 30 DAT & 45 DAT & 60 DAT & 75 DAT & 90 DAT & At harvest \\
\hline V1-Red rice (kondo dano) & 44.77 & 80.59 & 111.93 & 116.41 & 125.37 & 129.40 \\
\hline V3-Balami & 40.95 & 61.42 & 85.99 & 90.09 & 92.13 & 102.37 \\
\hline V4-Dudheswar & 51.36 & 92.44 & 128.40 & 133.53 & 143.80 & 148.43 \\
\hline C.D. $(p=0.05)$ & 3.89 & 8.027 & 11.445 & 12.188 & 12.955 & 13.029 \\
\hline C.V. (\%) & 5.460 & 6.253 & 6.361 & 6.459 & 6.461 & 6.257 \\
\hline
\end{tabular}

Table 2: Dry matter accumulation $\left(\mathrm{g} / \mathrm{m}^{2}\right)$ of traditional rice varieties under System of Rice Intensification (SRI)

\begin{tabular}{|c|c|c|c|c|c|c|}
\hline Treatment & \multicolumn{6}{|c|}{ Dry matter accumulation $\left(\mathrm{g} / \mathrm{m}^{2}\right)$} \\
\hline V1-Red rice (kondo dano) & 161.44 & 304.40 & 476.80 & 691.10 & 819.10 & 966.40 \\
\hline V2-Manipuri black rice & 103.40 & 267.20 & 498.96 & 787.00 & 961.90 & 1148.40 \\
\hline V3-Balami & 140.98 & 296.00 & 479.08 & 736.08 & 893.50 & 1081.20 \\
\hline C.D. $(p=0.05)$ & 15.62 & 34.33 & 49.43 & 86.62 & 84.31 & 98.25 \\
\hline C.V. (\%) & 6.19 & 6.50 & 5.68 & 6.68 & 5.40 & 5.33 \\
\hline
\end{tabular}

Table 3: Leaf Area Index (LAI) of traditional rice varieties under System of Rice Intensification (SRI)

\begin{tabular}{|c|c|c|c|c|c|c|}
\hline \multirow{2}{*}{ Treatment } & \multicolumn{6}{|c|}{ Leaf Area Index (LAI) } \\
\hline & 30 DAT & 45 DAT & 60 DAT & 75 DAT & 90 DAT & At harvest \\
\hline V1-Red rice (kondo dano) & 1.49 & 1.91 & 2.59 & 3.54 & 2.44 & 1.76 \\
\hline V2-Manipuri black rice & 0.92 & 1.47 & 2.38 & 3.46 & 2.76 & 1.30 \\
\hline V3-Balami & 0.94 & 1.05 & 2.25 & 3.40 & 2.63 & 1.48 \\
\hline V4-Dudheswar & 2.30 & 2.68 & 3.28 & 3.88 & 2.48 & 1.46 \\
\hline S. Em. ( $( \pm)$ & 0.055 & 0.098 & 0.083 & 0.107 & 0.072 & 0.178 \\
\hline C.D. $(p=0.05)$ & 0.17 & 0.31 & 0.26 & 0.34 & 0.23 & NS \\
\hline C.V. $(\%)$ & 7.83 & 11.03 & 6.36 & 5.98 & 5.61 & - \\
\hline
\end{tabular}

Table 4: Crop growth rate $\left(\mathrm{g} \mathrm{m}^{-2} \mathrm{day}^{-1}\right)$ of traditional rice varieties under System of Rice Intensification (SRI)

\begin{tabular}{|c|c|c|c|c|c|c|}
\hline \multirow{2}{*}{ Treatment } & \multicolumn{6}{|c|}{ Crop growth rate $\left(\mathrm{g} \mathrm{m}^{-2} \mathrm{day}^{-1}\right)$} \\
\hline & 0-30 DAT & 30-45 DAT & 45-60 DAT & 60-75 DAT & 75-90 DAT & 90DAT-at harvest \\
\hline V1-Red rice (kondo dano) & 5.38 & 9.53 & 11.49 & 14.28 & 8.53 & 5.66 \\
\hline V2-Manipuri black rice & 3.44 & 14.25 & 15.45 & 19.20 & 11.66 & 7.17 \\
\hline V3 -Balami & 4.70 & 10.33 & 12.20 & 17.13 & 10.49 & 7.22 \\
\hline V4-Dudheswar & 7.52 & 15.12 & 17.77 & 20.62 & 13.28 & 7.37 \\
\hline S. Em. ( \pm$)$ & 0.163 & 0.756 & 0.646 & 1.310 & 0.457 & 0.375 \\
\hline C.D. $(p=0.05)$ & 0.52 & 2.42 & 2.06 & 4.19 & 1.46 & 1.20 \\
\hline C.V. (\%) & 6.19 & 12.29 & 9.08 & 14.71 & 8.31 & 10.94 \\
\hline
\end{tabular}


Table 5: Yield attributing characters and yield $\left(\mathrm{kg} \mathrm{ha}^{-1}\right)$ of traditional rice varieties under System of Rice Intensification (SRI)

\begin{tabular}{|c|c|c|c|c|c|c|c|c|}
\hline \multirow[b]{2}{*}{ Treatments } & \multicolumn{4}{|c|}{ Yield Attributes } & \multicolumn{4}{|c|}{ Yield (kg ha-1) } \\
\hline & $\begin{array}{c}\text { Number } \\
\text { of tillers } \\
\text { plant }^{-1}\end{array}$ & $\begin{array}{l}\text { Number } \\
\text { of panicles } \\
\text { plant }^{-1}\end{array}$ & $\begin{array}{l}\text { Number } \\
\text { of grains } \\
\text { panicle }^{-1}\end{array}$ & $\begin{array}{c}\text { Number } \\
\text { of grains } \\
\text { plant }^{-1}\end{array}$ & $\begin{array}{c}\text { Grain } \\
\text { weight } \\
\text { plant }^{-1}(g)\end{array}$ & $\begin{array}{l}1000 \text { grain } \\
\text { weight }(\mathrm{g})\end{array}$ & $\begin{array}{c}\text { Grain } \\
\text { yield (kg } \\
\left.\text { ha }^{-1}\right)\end{array}$ & $\begin{array}{c}\text { Straw } \\
\text { yield (kg } \\
\left.\text { ha-1) }^{-1}\right)\end{array}$ \\
\hline V1-Red rice (kondo dano) & 12.67 & 11.55 & 177.95 & 1144.15 & 18.73 & 16.58 & 2998.00 & 6002.25 \\
\hline V2-Manipuri black rice & 18.67 & 15.65 & 125.25 & 1948.50 & 39.64 & 20.32 & 6343.00 & 7138.00 \\
\hline V3-Balami & 23.40 & 16.05 & 88.80 & 1308.00 & 28.18 & 21.35 & 4509.50 & 8272.00 \\
\hline V4-Dudheswar & 29.40 & 19.30 & 123.15 & 2380.50 & 41.00 & 22.19 & 6560.25 & 10632.00 \\
\hline S. Em. $( \pm)$ & 1.541 & 0.665 & 4.664 & 52.426 & 1.734 & 0.724 & 164.392 & 342.951 \\
\hline C.D. $(p=0.05$ & 4.93 & 2.13 & 14.92 & 167.72 & 5.55 & 2.31 & 525.92 & 1097.16 \\
\hline C.V. (\%) & 14.65 & 8.51 & 7.24 & 6.18 & 10.87 & 7.20 & 6.44 & 8.56 \\
\hline
\end{tabular}

Table 6: Economics of traditional rice varieties under System of Rice Intensification (SRI)

\begin{tabular}{cccccc}
\hline S1. No. & Treatments & $\begin{array}{c}\text { Cost of } \\
\text { Production } \\
\left(₹ \text { ha }^{-1}\right)\end{array}$ & $\begin{array}{c}\text { Gross return } \\
\left(₹ \text { ha }^{-1}\right)\end{array}$ & $\begin{array}{c}\text { Net return } \\
\left(₹ \text { ha }^{-1}\right)\end{array}$ & $\begin{array}{c}\text { Benefit: cost } \\
\text { Ratio }\end{array}$ \\
\hline 1 & $V_{1}$-Red rice (kondo dano) & 45950 & 59966.25 & 14016.25 & 0.30 \\
2 & $V_{2}$-Manipuri black rice & 47990 & 165713 & 117723 & 2.45 \\
3 & $V_{3}$-Balami & 45950 & 89443 & 43493 & 0.94 \\
4 & $V_{4}$-Dudheshwar & 45910 & 128716.5 & 82806.5 & 1.80 \\
\hline
\end{tabular}

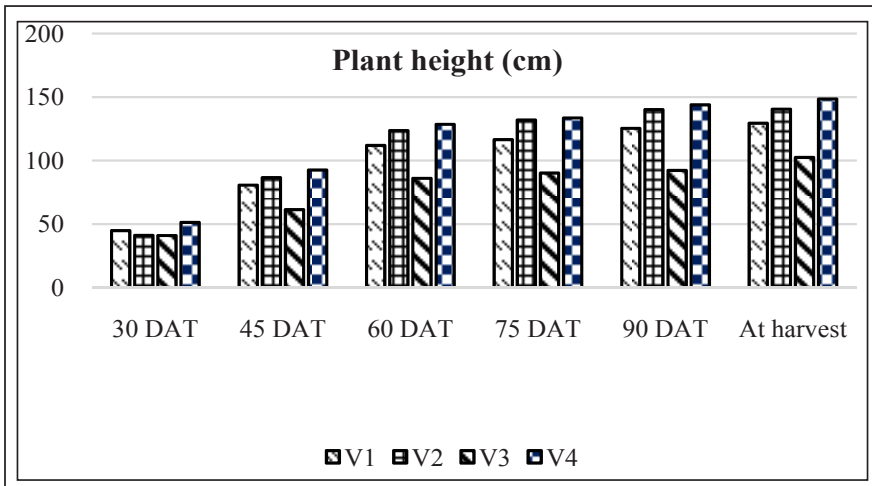

Fig. 1: Plant height $(\mathrm{cm})$ of traditional rice varieties under SRI

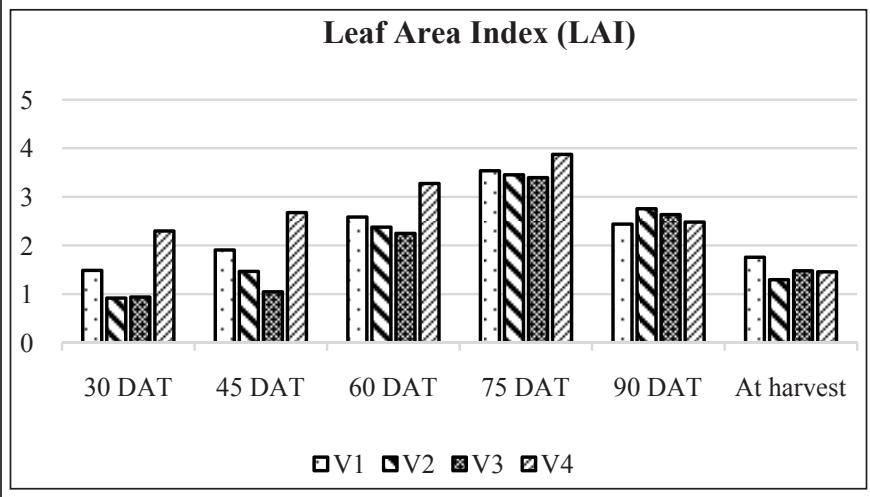

Fig. 3: Leaf area indices (LAI) of traditional rice varieties under SRI

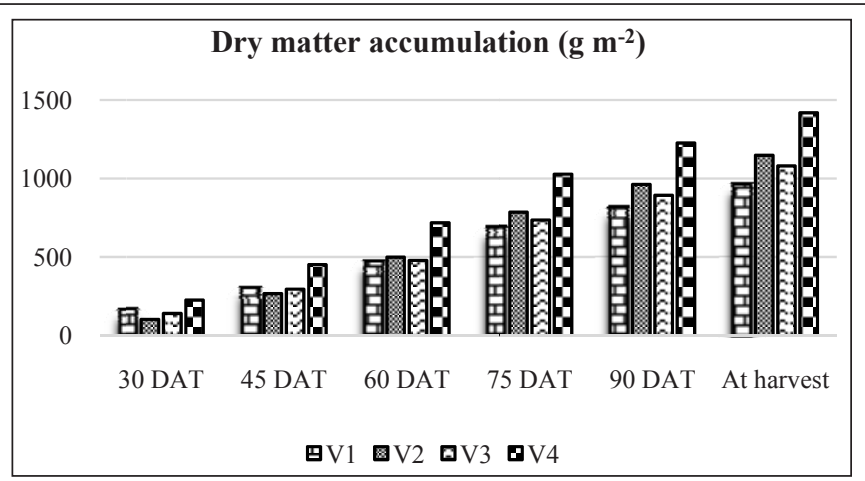

Fig. 2: Dry matter accumulation $\left(\mathrm{g} / \mathrm{m}^{2}\right)$ of traditional rice varieties under SRI

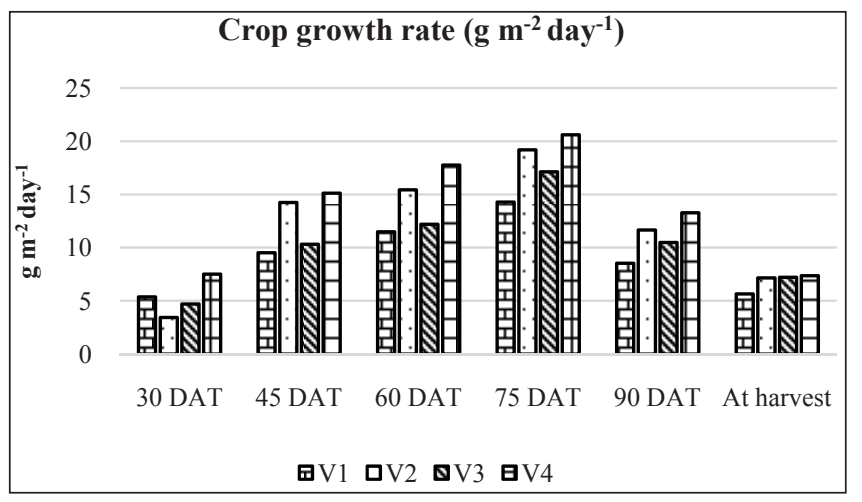

Fig. 4: Crop growth rate $\left(\mathrm{g} \mathrm{m}^{-2} \mathrm{day}^{-1}\right)$ of traditional rice varieties under SRI 
Between 90 DAT- at harvest, traditional rice varieties did not show any significant effect on crop growth rate. The highest crop growth rate $\left(7.37 \mathrm{~g} \mathrm{~m}^{-2}\right.$ day $\left.^{-1}\right)$ was found in treatment $\mathrm{V}_{4}$ (Dudheshwar) followed by $\mathrm{V}_{3}$ (Balami) and $\mathrm{V}_{2}$ (Manipuri black rice), which

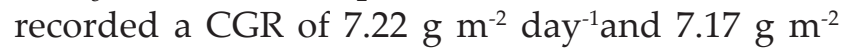
day $^{-1}$, respectively.

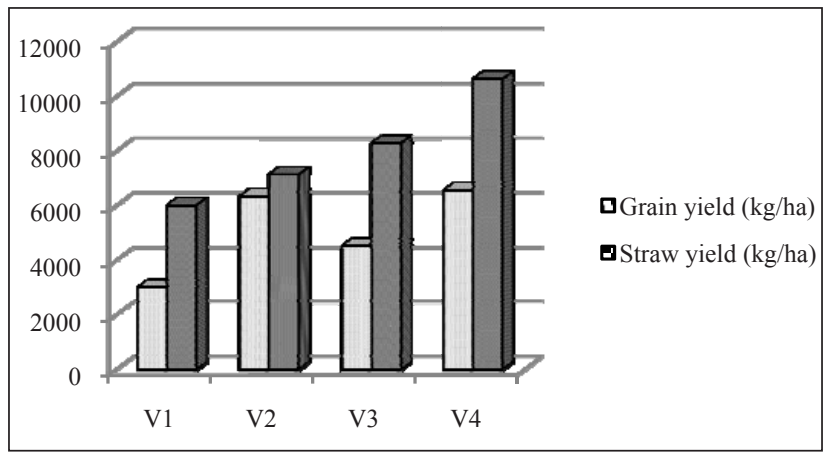

Fig. 5: Grain and straw yield of traditional rice varieties under SRI

\section{Yield Attributes and Yield}

The yield attributing characters and yield of traditional rice varieties were influenced significantly under system of rice intensification. Yield attributes like Number of tiller plant ${ }^{-1}$, Number of panicle plant $^{-1}$, Number of grains plant ${ }^{-1}$, Grain weight plant $^{-1}(\mathrm{~g})$ and 1000 grain weight $(\mathrm{g})$ were maximum under treatment $\mathrm{V}_{4}$-Dudheshwar, (Table 1 and Fig. 1 to 4 ). But Number of grains panicle ${ }^{-1}$ was maximum under $\mathrm{V}_{1}$, Red rice (kondo dano). Highest grain yield $\left(\mathrm{kg} \mathrm{ha}^{-1}\right)$ and straw yield $\left(\mathrm{kg} \mathrm{ha}^{-1}\right)$ were achieved by treatment $\mathrm{V}_{4^{\prime}}$ Dudheshwar. The results are in conformity with the findings of Ahmed et al. (2015), Hamid et al. (2015), Ullah et al. (2016) and Poudel (2018) where the researchers noted variation among growth paramater, yield attributes and yield among different traditional varieties.

\section{Economics}

The total cost of cultivation was calculated considering the expenditure on land preparation, seed materials, fertilizer application, transplanting, weeding, harvesting, threshing, irrigation and so on. The maximum cost of production ( $₹ 47,990 \mathrm{ha}^{-1}$ ) was recorded by $V_{2}$, Manipuri black rice followed by $\mathrm{V}_{1}$, Red rice (kondo dano), and $\mathrm{V}_{3^{\prime}}$ Balami (Table 6). Highest gross return of (₹ $\left.1,65,713 \mathrm{ha}^{-1}\right)$ was recorded by $\mathrm{V}_{2}$, Manipuri black rice and the lowest gross return ( $₹ 59,966$ ha-1 $^{-1}$ ) was recorded by $\mathrm{V}_{1^{\prime}}$ Red rice (kondo dano). Maximum net return of (₹ $1,17,723 \mathrm{ha}^{-1}$ ) was recorded by $\mathrm{V}_{2^{\prime}}$ Manipuri black rice, whereas the lowest gross return (₹ 14,016.25 $\mathrm{ha}^{-1}$ ) was recorded by $\mathrm{V}_{1}$, Red rice (kondo dano). In terms of benefit : cost ratio, the highest value (2.45) was recorded by the treatment $\mathrm{V}_{2}$, Manipuri black rice and the lowest benefit : cost ratio (0.30) was recorded by $\mathrm{V}_{1}$, Red rice (kondo dano). The highest net return and $B: C$ ratio were obtained with the variety Manipuri black rice, because of its higher market price.

\section{CONCLUSION}

From the present investigation, it may be concluded that, the variety Dudheshwar may be chosen for achieving higher yield of rice, but in terms of economics and profitability, the variety Manipuri black rice can be preferred than other traditional rice varieties.

\section{ACKNOWLEDGEMENTS}

The authors are grateful to the authority of M.S. Swaminathan School of Agriculture, Centurion University of Technology and Management for funding and necessary support to carry out the experiment.

\section{REFERENCES}

Ahmed, A.R., Dutta, B.K. and Ray, D.C. 2015. Response of Some Rice Varieties to Different Crop Management Practices towards Morphological and Yield Parameters, International Journal of Scientific and Research Publications, 5(2): 1-6.

Anonymous, 2015. Ministry of Agriculture, Directorate of Economics and Statistics, Government of India.

Anonymous, 2016. Agricultural statistics at a glance, Department of Agriculture Economics and Statistics, Ministry of Agriculture, New Delhi.

Chaudhury, R.C. et al. 2003. Specialty of the World Breeding, Production and Marketing. Food and Agriculture Organisation (FAO), Rome in Association with Science Publishers Inc., New Hampshire, USA.

Hamid, A., Ullah, M.J., Mollah, M.F.H. and Akbar, M.A. 2015. Traditional rice varieties perform better in tidal floodplain. Intl. J. Adv. Res., 3: 1316-1321.

Ullah, Mohammad Jafar, Aminul Islam, M., Harun-or-Rashid, M, Moksedur Rahman, M, Siddique, M.A., Ali Akbar, M. Mohammad Abdur Razzaque, M. Faruque H. Mollah, 
2 Manikanta et al.

Abdul Hamid, 2016. Evaluation of Indigenous and High Yielding Rice Varieties for Growing in Tidal Floodplain Ecosystem of Southern Bangladesh, Agriculture, Forestry and Fisheries, 5(6): 237-242.
Khatana, V. 2004.Western Orissa Livelihood Project. Prepared with assistance of DFID and Government of Orissa. 